\title{
PENGARUH ATRIBUT PRODUK TERHADAP MINAT BELI SEPEDA MOTOR HONDA DEALER AMANAH LUBUK ALUNG
}

\author{
Suci Ramadani, Nazaruddin Aziz \\ Sekolah Tinggi Ilmu Ekonomi "KBP" \\ nazaruddinaziz@akbpstie.ac.id
}

\begin{abstract}
The formulation of the problem is to know how attribute influence to buying interest of motorcycle product of honda brand. From the results of the research can be known responses of respondents about the product attributes can be said quite well which resulted to the good interest in buying a motorcycle brand Honda. Based on the test attribute to consumer buying interest found sig or probality value for attribute variable that is, product quality $0.000<\alpha=0,05$ product design $0,000<\alpha=0,05$, product service 0,003 $<\alpha=0,005$, for that decision is ha received and Ho rejected. Means it can be concluded that the variables, product quality, product design and product services have a significant influence on the interest of buying motorcycles honda brand. While product price variable found sig and probality value for product price variable 0,336 $<\alpha=0,05$ for that decision is Ha rejected and Ha in receipt, it can be concluded that variable of product price have insignificant influence to buying interest of motorcycle product brand honda. In the test value of $F$ to measure the effect of attribute variables are product quality, product design, product service and product price found sig $0.000<\alpha=0.05$ then the decision is Ha accepted and Ho rejected, it means dapt concluded that each variable has a significant influence on the interest to buy motorcycle products honda brand motorcycles simultaneously.
\end{abstract}

Keywords : product quality, product design, product service, product price and buying interest

\section{PENDAHULUAN}

Perkembangan dunia usaha saat ini mengalami peningkatan yang sangat tajam. Kegiatan pemasaran sekarang sudah mulai difokuskan pada pemuasan kebutuhan konsumen. Menurut Kotler (2008:28) pemasaran adalah suatu proses sosial yang di dalamnya individu dan kelompok mendapatkan apa yang mereka butuhkan dan inginkan dengan menciptakan, menawarkan dan secara bebas mempertukarkan produk yang bernilai dengan pihak lain. Pemasaran itu sendiri sudah harus dipikirkan 
jauh hari sebelumnya, agar lebih tepat pada sasaran konsumen. Karena konsumen yang potensial akan mempertimbangkan berbagai faktor, diantaranya faktor kualitas produk, kepuasan konsumen dan fasilitas yang ada sebelum memilih tempat yang dapat memberikan kepuasan tertinggi terhadap konsumen.

Sepeda motor Honda merupakan kendaraan beroda dua yang bergerak oleh sebuah mesin, sepeda motor honda di dirikan oleh sechhiro honda pada tahun 1948. Masyrakat telah mengenal sepeda motor honda dan telah di jadikan sebagai alat transportasi yang banyak di minati masyarakat bandingkan dengan produk motor lainya, yang dapat di lihat pada tabel 1

Tabel 1

Top Brand Index(TBI) produk sepeda motor honda

Tahun 2013 - 2016

\begin{tabular}{|c|c|c|}
\hline Tahun & $\begin{array}{c}\text { produk } \\
\text { Honda }\end{array}$ & $\begin{array}{c}\text { produk } \\
\text { Yamaha }\end{array}$ \\
\hline 2013 & 765 & 421 \\
\hline 2014 & 930 & 390 \\
\hline 2015 & 735 & 420 \\
\hline 2016 & 862 & 861 \\
\hline
\end{tabular}

Sumber:data.penjualan.sepeda.motor.honda.amanah

Dari data di atas menunjukan bahwa honda lebih unggul di tahun 2013 di bandingkan dengan yamaha. Pada tahun 2014 dan 2016 honda memiliki penjualan paling tinggi dari produk pesaing yaitu 930 dan 862. pada tahun 2015 honda mengalami penurunan penjualan dari tahun sebelumnya . hal ini disebabkan semakin banyak berkembangan sepeda motor di masyarakat, namun demikian sepeda motor honda tetap unggul dari sepeda motor merk pesaing.

Selain itu, atribut produk juga termasuk salah satu hal yang perlu diperhatikan oleh perusahaan. Mengelola atribut produk dengan baik merupakan cara yang paling ampuh untuk menarik minat beli dalam keputusan pembelian produk. Atribut produk inilah yang akan membedakan antara produk yang ditawarkan oleh suatu perusahaan dengan produk sejenis yang ditawarkan perusahaan lain. Perbedaan atribut kemudian bisa menimbulkan perbedaan persepsi konsumen terhadap produk yang ditawarkan oleh berbagai perusahaan sehingga akhirnya dapat mempengaruhi konsumen dalam keputusan pembelian. 


\section{KAJIAN PUSTAKA \\ Pengertian minat beli}

Menurut Simamora (2002:131) minat beli adalah sesuatu yang pribadi dan berhubungan dengan sikap, individu yang berminat terhadap suatu obyek akan mempunyai kekuatan atau dorongan untuk melakukan serangkaian tingkah laku untuk mendekati atau mendapatkan objek tersebut. dan menjelaskan minat beli bahwa pengaruh eksternal, kesadaran akan kebutuhan, pengenalan produk dan evaluasi alternatif adalah hal yang dapat menimbulkan minat beli konsumen. Pengaruh eksternal ini terdiri dari usaha pemasaran dan faktor sosial budaya. Kanuk (2004:25),

\section{Atribut Produk}

Atribut produk merupakan salah satu hal penting yang perlu diperhatikan oleh perusahaan. Mengelola atribut produk dengan baik merupakan salah satu cara yang paling penting untuk menarik minat konsumen dalam keputusan pembelian produk.Menurut Tjiptono (2008:103) "Atribut produk adalah unsur-unsur produk yang dipandang penting oleh konsumen dan dijadikan dasar pengambilan keputusan pembelian".

1. Kualitas produk

Kualitas produk adalah keseluruhan dari ciri dan karakteristik suatu barang atau jasa yang berpengaruh pada kemampuannya untuk memuaskan kebutuhan yang dinyatakan maupun yang tersirat. (Kotler, 2002:).

2. Desain produk

Desain produk adalah masalah desain dari suatu produk telah menjadi salah satu faktor yang perlu mendapatkan perhatian serius dari manajemen khususnya team pengembangan produk baru, karena sasaran konsumen yang dituju tidak sedikit yang mulai mempersoalkan masalah desain suatu produk yang mampu memenuhi kebutuhan dan keinginan konsumen (Angipora, 2002).

3. Pelayanan produk

Menurut Lovelock (2002:5) Pelayanan adalah sebagai kegiatan ekonomi yang menciptakan dan memberikan manfaat bagi pelanggan pada waktu dan tempat tertentu, sebagai hasil dan tindakan mewujudkan perubahan yang diinginkan dalam diri atau atas nama penerima jasa tersebut

4. Harga produk

Harga adalah sejumlah uang yang ditagihkan atas sesuatu produk atau jasa atau jumlah dari nilai yang ditukarkan para konsumen untuk memperoleh manfaat dari memiliki atau menggunakan suatu produk atau jasa (Kotler dan Amstrong,2008:345)

\section{Hipotesis Penelitian}

H1:Diduga Terdapat pengaruh positif dan signifikan kualitas produk terhadap minat beli.

H2: Diduga Terdapat pengaruh positif dan signifikan desain produk terhadap minat beli.

H3: Diduga Terdapat pengaruh positif dan signifikan pelayanan produk terhadap minat beli. 
H4: Diduga Terdapat pengaruh positif dan signifikan harga produk terhadap minat beli.

\section{Jenis Penelitian}

Jenis penelitian ini adalah penelitian kuantitatif. Pendekatan kuantitatif adalah metode penelitian yang dgunakan untuk meneliti populasi atau sampel tertentu yang bertujuan untuk menguji hipotesis. Menggunakan statistik (sugiyono,2015).

Oleh karena itu, penelitian kuantitatif mengunakan skala numeric berbasis pola alur deduktif, dimana untuk menjawab rumusan masalah digunakan konsep atau teori sehingga dapat dirumuskan hipotesis. Tujuannya yaitu untuk menguji hipotesis yang ditetapkan.

\section{Populasi dan Sampel}

\section{Populasi}

Menurut Sugiyono (2008:115), "Populasi adalah wilayah generalisasi terdiri atas obyek/subyek yang mempunyai kualitas dan karakteristik tertentu, ditetapkan oleh peneliti untuk dipelajari dan kemudian ditarik kesimpulan. "Populasi dalam penelitian ini adalah seluruh pengguna sepeda motor honda di lubuk alung pada tahun 2016 sebanyak 862 orang, berdasarkan sumber dari dialer amanah sepeda motor honda yang ada di lubuk alung.

2 sampel

Sampel dalam penelitian ini adalah bagian dari populasi yang akan diteliti. Metode pengambilan sampel dilakukan dengan cara Accidental sampling yaitu bentuk pengambilan sampel berdasarkan kebetulan dimana, siapa saja yang kebetulan bertemu dengan peneliti dan dianggap cocok menjadi sumber data yang akan menjadi sampel penelitian (Sugiyono,2001).

\section{HASIL DAN PEMBAHASAN.}

\section{Uji Validitas}

\section{Atribut produk}

a.Kualitas Produk

\begin{tabular}{|c|c|c|c|}
\hline No & $\begin{array}{l}\text { Pertanyaan yang berkaitan dengan } \\
\text { Kualitas produk }\end{array}$ & $\begin{array}{l}\text { Corrected Item- } \\
\text { Total Correlation }\end{array}$ & Keterangan \\
\hline 1. & $\begin{array}{l}\text { Kualitas sepeda motor Honda sesuai } \\
\text { dengan iklan yang ada di tv. }\end{array}$ & 0.93 & $\begin{array}{l}\text { Tidak } \\
\text { Valid }\end{array}$ \\
\hline 2 . & $\begin{array}{l}\text { Produk ini ada banyak keistimewaannya } \\
\text { dibandingkan dengan produk lain. }\end{array}$ & .637 & Valid \\
\hline 3. & $\begin{array}{l}\text { Mengeluarkan produk-produk yang } \\
\text { sangat menarik. }\end{array}$ & .517 & Valid \\
\hline 4. & $\begin{array}{l}\text { Sales promotion produk ini culkkup baik } \\
\text { dalam menyampaikan informasi }\end{array}$ & .653 & Valid \\
\hline
\end{tabular}


Dari tabel 4.5 dapat di ambil kesimpulan bahwa 4 butir pertanyaan variabel Kualitas produk dikatakan 3 valid karena nilai corrected Item-Total correlation melebihi 0,300 sehingga dapat digunakan untuk penelitian lebih lanjut dan satu tidak valid karena nilai corrected item-Total Corelation kurang dari 0,300 sehingga tidak dapat digunakan un tuk penelitian lebih lanjut.

b. Desain produk

\section{Tabel 4.6}

Hasil Uji Validitas variabel Desain produk

\begin{tabular}{|l|l|l|l|}
\hline No & $\begin{array}{l}\text { Pertanyaan yang berkaitan } \\
\text { dengan desain produk }\end{array}$ & $\begin{array}{l}\text { Corrected } \\
\text { Item-Total } \\
\text { Correlation }\end{array}$ & Keterangan \\
\hline 1. & $\begin{array}{l}\text { Sepeda motor honda memiliki } \\
\text { ciri khas ters endiri. }\end{array}$ & .545 & Valid \\
\hline 2. & $\begin{array}{l}\text { Sepeda motor honda handal } \\
\text { dalam brkendara. }\end{array}$ & .675 & Valid \\
\hline 3. & $\begin{array}{l}\text { Dapat memenuhi semua yang di } \\
\text { janjikan oleh sepeda motor honda } \\
\text { sesuai yang dikatakan } \\
\text { karyawannya. }\end{array}$ & .722 & Valid \\
\hline 4. & $\begin{array}{l}\text { Sepeda motor mengeluarkan } \\
\text { produk yang unggul dan tahan } \\
\text { lama. }\end{array}$ & .675 & Valid \\
\hline 5. & $\begin{array}{l}\text { Sepeda motor honda memberikan } \\
\text { garansi servis gratis. }\end{array}$ & .762 & Valid \\
\hline 6. & $\begin{array}{l}\text { Model sepeda motor honda } \\
\text { sangat menarik. }\end{array}$ & .713 & Valid \\
\hline Sumber : data olahan 2017 & & \\
\hline
\end{tabular}

Dari tabel 4.6 dapat di ambil kesimpulan bahwa 6 butir pertanyaan variabel Desain Produk dikatakan valid karena nilai corrected Item-Total correlation melebihi 0,300 sehingga dapat digunakan untuk penelitian lebih lanjut. 
c. Pelayanan Dari Produk

\begin{tabular}{|l|l|c|l|}
\hline \multicolumn{3}{|c|}{ Hasil uji validitas variabel pelayanan Dari produk } \\
\hline 1. & $\begin{array}{l}\text { Pertanyaan yang berkaitan dengan } \\
\text { pelayanan dari produk }\end{array}$ & $\begin{array}{l}\text { Corrected Item- } \\
\text { Total Correlation } \\
\text { oleh karyawan sepeda motor Honda }\end{array}$ & Keterangan \\
\hline 3. & $\begin{array}{l}\text { Sepeda motor honda memberikan } \\
\text { pelayanan sesuai janjinya }\end{array}$ & .643 & Valid \\
\hline 4. & $\begin{array}{l}\text { Kesigapan dari dari karyawan dapat } \\
\text { membantu konsumennya. }\end{array}$ & .396 & Valid \\
\hline tamah serta sopan santun & $\begin{array}{l}\text { Menberikan penjelasan mengenail sepeda } \\
\text { motor honda kepada konsumen. }\end{array}$ & .674 & Valid \\
\hline Sumber : data olahan 2017 & .588 & Valid \\
\hline
\end{tabular}

Sumber : data olahan 2017

Dari tabel 4.7 dapat di ambil kesimpulan bahwa 5 butir pertanyaan variabel Pelayanan dari produk dikatakan valid karena nilai corrected Item-Total correlation melebihi 0,300 sehingga dapat digunakan untuk penelitian lebih lanjut d. Harga Produk

\begin{tabular}{|c|c|c|c|}
\hline \multicolumn{4}{|c|}{$\begin{array}{l}\text { Tabel } 4.8 \\
\text { Hasil Uji Validitas Variabel Harga produk }\end{array}$} \\
\hline No & Pertanyaan yang berkaitan dengan & $\begin{array}{l}\text { Corrected Item- } \\
\text { Total Correlation }\end{array}$ & $\begin{array}{l}\text { Keteranga } \\
\text { n }\end{array}$ \\
\hline 1. & $\begin{array}{l}\text { Harga sepeda motor honda cukup } \\
\text { terjangkau di semua kalangan. }\end{array}$ & .523 & Valid \\
\hline 2. & $\begin{array}{l}\text { Sepeda motor Honda memberikan } \\
\text { diskon atau potongan harga kepada } \\
\text { konsumen }\end{array}$ & .577 & Valid \\
\hline 3. & $\begin{array}{l}\text { Memberikan kemudahan dalam } \\
\text { melakukan pembayaran setiap } \\
\text { pembelian sepeda motor honda. }\end{array}$ & .843 & Valid \\
\hline 4. & $\begin{array}{l}\text { Harga sesuai dengan sepeda motor } \\
\text { honda yang di tawarkan. }\end{array}$ & .498 & Valid \\
\hline
\end{tabular}


Dari tabel 4.8 dapat di ambil kesimpulan bahwa 4 butir pertanyaan variabel Harga produk dikatakan valid karena nilai corrected Item-Total correlation melebihi 0,300 sehingga dapat digunakan untuk penelitian lebih lanjut.

\section{Minat Beli konsumen}

Tabel 4.9

\begin{tabular}{|c|c|c|c|}
\hline No & $\begin{array}{l}\text { Pertanyaan yang berkaitan dengan } \\
\text { Minat beli konsumen }\end{array}$ & $\begin{array}{l}\text { Corrected Item- } \\
\text { Total } \\
\text { Correlation }\end{array}$ & Keterangan \\
\hline 1. & $\begin{array}{l}\text { Saya bersedia merekomendasikan sepeda } \\
\text { motor honda kepada orang lain. }\end{array}$ & .433 & Valid \\
\hline 2. & $\begin{array}{l}\text { Saya ingin menceritakan kepada orang } \\
\text { lain tentang kelebihan sepeda motor } \\
\text { honda }\end{array}$ & .622 & Valid \\
\hline 3. & $\begin{array}{l}\text { Perusahaan sepeda motor honda sudah } \\
\text { lama berdiri }\end{array}$ & .576 & Valid \\
\hline 4. & $\begin{array}{l}\text { Sepeda motor honda tetap di hati saya, } \\
\text { sehingga tidak mudah berpaling ke } \\
\text { produk lain }\end{array}$ & .550 & Valid \\
\hline 5. & $\begin{array}{l}\text { Sepeda motor honda memiliki ke } \\
\text { unggulan dari sepeda motor lain. }\end{array}$ & .564 & Valid \\
\hline 6. & $\begin{array}{l}\text { Jika ada sales promosi dari sepeda motor } \\
\text { honda lain merek yang lain, saya tidak } \\
\text { akan berpaling dari sepeda motor honda. }\end{array}$ & .689 & Valid \\
\hline 7 & $\begin{array}{l}\text { Pencantuman harga sepeda motor honda } \\
\text { jelas dan tidak membingungkan }\end{array}$ & .729 & Valid \\
\hline 8. & $\begin{array}{l}\text { Kualitas sepeda motor honda yang di } \\
\text { tawarkan memiliki kualitas tinggi }\end{array}$ & .706 & Valid \\
\hline 9. & $\begin{array}{l}\text { Jenis Sepeda motor honda yang di } \\
\text { tawarkan layak untuk di jual }\end{array}$ & .698 & Valid \\
\hline 10. & $\begin{array}{l}\text { Jenis sepeda motor honda yang di } \\
\text { tawarkan sesuai kebutuhan }\end{array}$ & .667 & Valid \\
\hline 11. & $\begin{array}{l}\text { Sepeda motor honda yang di tawarkan } \\
\text { layak untuk dipakai }\end{array}$ & .668 & Valid \\
\hline
\end{tabular}

Sumber : data olahan 2017

Dari tabel 4.9 dapat di ambil kesimpulan bahwa 11 butir pertanyaan variabel Minat beli dikatakan valid karena nilai corrected Item-Total correlation melebihi 0,300 sehingga dapat digunakan untuk penelitian lebih lanjut. 


\section{Uji Realibilitas}

Tabel 4.10

Hasil Uji Reliabiliti

\begin{tabular}{|c|l|c|c|}
\hline No & Variabel & Cronbach's Alpha & Keterangan \\
\hline 1. & Kualitas Produk. & .764 & Reliabel \\
\hline 2. & Desain Produk & .875 & Reliabel \\
\hline 3. & Pelayanan Dari produk & 802 & Reliabel \\
\hline 4. & Harga produk & 782 & Reliabel \\
\hline 5. & Minata beli & .896 & Reliabel \\
\hline
\end{tabular}

Sumber : Olahan data 2017

Dari tabel 4.10 dapat di ambil kesimpulan bahwa dari uji reliabilitas dihasilkan nilai Cronbach's Alpha untuk variabel penelitian yaitu kualitas produk, desain produk, pelayanan dari produk, harga produk, dan minat beli lebih besar dari 0,60 yang memberikan hasil bahwa variabel yang diteliti memenuhi syarat konsistensi (reliabilitas). Jadi, item-item pertanyaan untuk variabel penelitian dapat dipakai sebagai alat ukur dalam penelitian.

\section{Uji Asumsi Klasik}

\section{Uji Normalitas}

\begin{tabular}{|c|c|c|}
\hline \multicolumn{3}{|c|}{ Tabel 4.16} \\
\hline \multicolumn{3}{|c|}{ Hasil penguji Normalitas Data } \\
\hline \multicolumn{3}{|c|}{ One-Sample Kolmogorov-Smirnov Test } \\
\hline & & 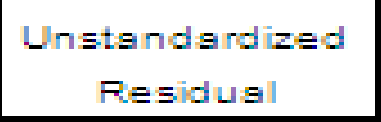 \\
\hline $\mathbb{N}$ & & 49 \\
\hline \multirow[t]{2}{*}{ Nomall Plarameter: } & Mean & .0000000 \\
\hline & Std. Deviation & 87152069 \\
\hline \multirow[t]{3}{*}{ Most Extreme Differences } & Absolute & 125 \\
\hline & Positive & 125 \\
\hline & Negative & -.057 \\
\hline \multicolumn{2}{|l|}{ Kolmogorow-Smimov $z$} & 875 \\
\hline \multicolumn{2}{|l|}{ Asymp. Sig. (2-tailed) } & .428 \\
\hline \multirow{2}{*}{\multicolumn{2}{|c|}{ a. Test distribution is Normal. }} & \\
\hline & & \\
\hline
\end{tabular}


Dari tabel terlihat bahwa hasil uji normalitas menyatakan nilai kolmogrov sminov $Z \quad 0,428$ dengan signifikan 0,875 . Berdasarkan hasil tersebut maka dapat dinyatakan data yang digunakan dalam penelitian ini telah terdistribusi normal, karena nilai signifikan $87.5>0,05$.

\section{Uji Multikoleniaritas}

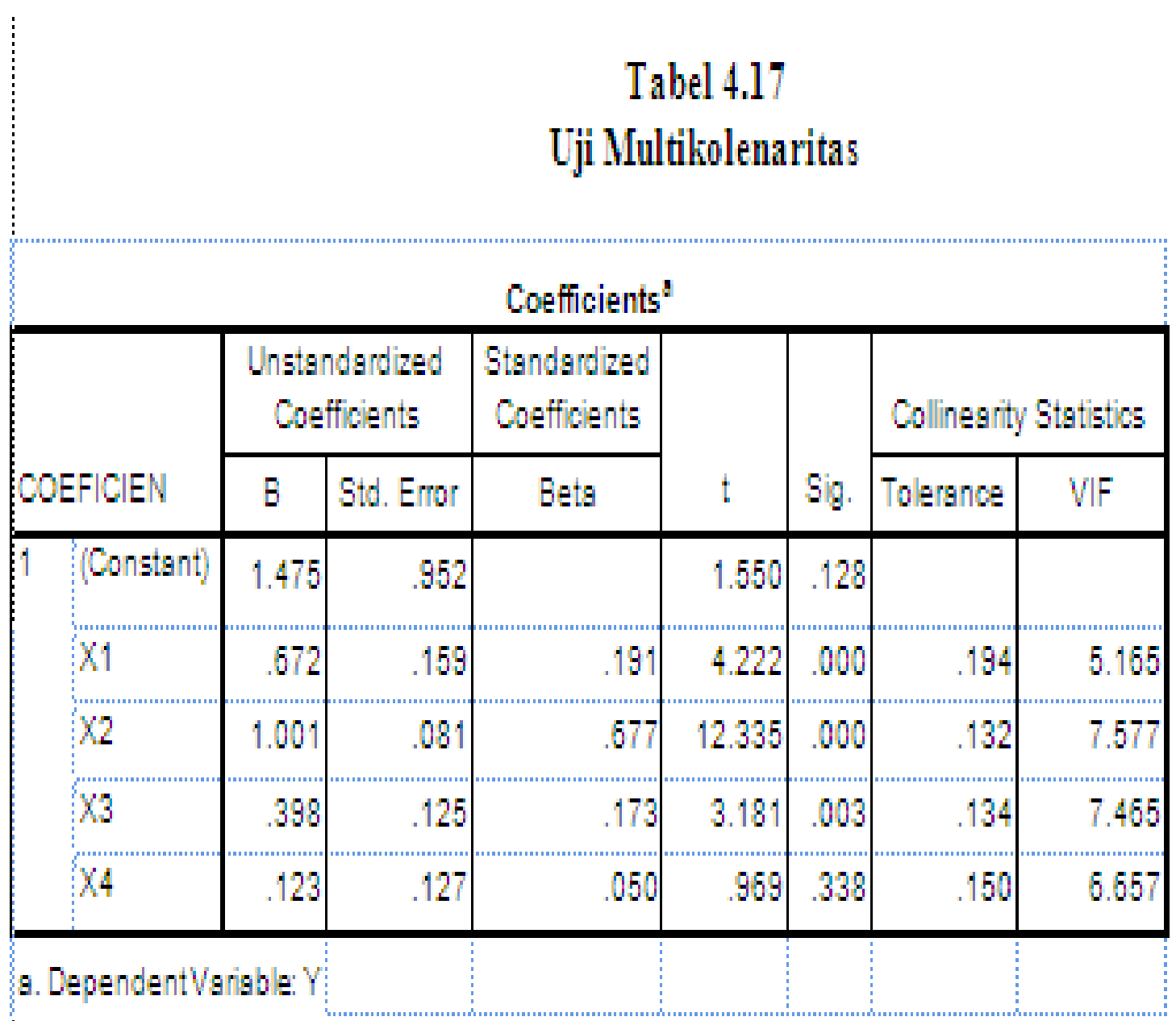

Berdasarkan tabel diatas dapat diketahui bahwa nilai tolerence variabel independen sebesar 0, 194(X1), 0,132(X2), 0.134 (X3), 0,150(X4) jauh berbeda diatas patokan 0,10, yaitu 5.165 (X1) dan 7.577(X2), 7.465 (X3), 6.657(X4). Hal ini berarti bahwa hasil analisis menunjukan tidak ada masalah multikolonieritas sehingga pengujian layak menggunakan model regresi berganda. 


\section{Uji Heterokedastisitas}

Tabel 4.18

Uji Heterokedastisitas

\begin{tabular}{|c|c|c|c|c|c|}
\hline & \multicolumn{2}{|c|}{ Unstandardized Coefficients } & \multirow{2}{*}{$\begin{array}{c}\text { Standardized } \\
\text { Coefficients }\end{array}$} & \multirow[b]{2}{*}{$\mathrm{t}$} & \multirow[b]{2}{*}{ Sig. } \\
\hline & B & Std. Error & & & \\
\hline $1 \quad$ (Constant) & 1.475 & .952 & & 1.550 & .128 \\
\hline $\mathrm{X} 1$ & .672 & .159 & 191 & 4.222 & .000 \\
\hline $\mathrm{X} 2$ & 1.001 & .081 & .677 & 12.335 & .000 \\
\hline X3 & .398 & .125 & .173 & 3.181 & .003 \\
\hline $\mathrm{X} 4$ & .123 & .127 & .050 & .969 & .338 \\
\hline
\end{tabular}

a. Dependent Variable: Y

Dari tabel diatas di ketahui bahwa nilai kedua variabel independen dilihat dari nilai signifikan $<0,05$ dilihat dari nilai sig yaitu variabel kualitas produk ( X1) 0 , $000<0,5$, dan desain produk (X2 ) 0,00 $<0,5$, pelayanan produk (X3) $0,003<0,5$, Harga produk (X4) $0,338<0,5$. dengan demikian dapat disimpulkan bahwa tidak terjadi masalah pada heterokedastisitas pada model regresi

Analisis linear Berganda

Table 4.19

Hasil Uji Analisis Regression Linear Berganda

Coefficients $^{\mathrm{a}}$

\begin{tabular}{|c|c|c|c|c|c|}
\hline & \multicolumn{2}{|c|}{ Unstandardized Coefficients } & \multirow{2}{*}{\begin{tabular}{|c|}
$\begin{array}{c}\text { Standardized } \\
\text { Coefficients }\end{array}$ \\
Beta \\
\end{tabular}} & \multirow[b]{2}{*}{$\mathrm{t}$} & \multirow[b]{2}{*}{ Sig. } \\
\hline & B & Std. Error & & & \\
\hline 1 (Constant) & 1.475 & .952 & & 1.550 & .128 \\
\hline $\mathrm{X} 1$ & .672 & .159 & .191 & 4.222 & .000 \\
\hline $\mathrm{X} 2$ & 1.001 & .081 & .677 & 12.335 & .000 \\
\hline $\mathrm{X} 3$ & .398 & .125 & .173 & 3.181 & .003 \\
\hline $\mathrm{X} 4$ & .123 & .127 & .050 & 969 & .338 \\
\hline
\end{tabular}

a. Dependent Variable: Y

Berdasarkan tabel 4.19 maka ringkasan hasil pengujian dapat diformulasikan persamaan regresinya sebagai berikut.

$\mathrm{Y}=1.475+0,672+1001+0,398+0,123$

Dari persamaan regresi diatas, dapat diinterprestasikan sebagai berikut : 
1. $\mathrm{a}=1.475$ artinya tampa variabel bebas ( variabel $\mathrm{X}$ ) maka minat beli sepeda motor honda dialer amanah lubuk alung adalah 1.475 dengan asumsi variabel bebas yuitu kualitas produk, desain produk, pelayanan dari produk, harga produk tidak mengalami perubahan.

2. $\mathrm{b} 1=$ koefisien regresi 0.672 menunjukan bahwa setiap variabel kualitas produk bertambah 1 poin, maka peningkatan minat beli sepeda motor honda akan bertambah sebesar 0.672dengan asumsi variabel kualitas produk dianggap tetap.

3. b2 = koefisien regresi 0,1001 menunjukan bahwa setiap variabel desain produk bertambah 1 poin, maka peningkatan minat beli sepeda motor honda akan bertambah sebesar 0.1001 dengan asumsi variabel desain produk dianggap tetap.

4. $b 3=$ koefisien regresi 0.398 menunjukan bahwa setiap variabel pelayanan dari produk bertambah 1 poin, maka peningkatan minat beli sepeda motor honda akan bertambah sebesar 0.398dengan asumsi variabel pelayanan dari produk dianggap tidak tetap.

5. b4= koefisien regresi 0.123 menunjukan bahwa setiap variabel harga produk bertambah 1 poin, maka peningkatan minat beli sepeda motor honda akan bertambah sebesar 0.123 dengan asumsi variabel harga produk dianggap tetap.

\section{Uji Hipotesis}

\section{Uji t}

Berdasarkan hasil uji t yang dilakukan dengan menggunakan program SPSS for windows dikemukakan hasil seperti tabel 4.21

\section{Tabel 4.21}

Hasil Uji t

\begin{tabular}{|l|r|r|l|l|}
\hline Variabel & \multicolumn{1}{|l|}{ t-hit } & \multicolumn{1}{l|}{ Sig } & Alpha & Kesimpulan \\
\hline Kualitas produk & 4.222 & 0,000 & 0,05 & Signifikan \\
\hline Desain produk & 12.335 & 0,000 & 0,05 & Signifikan \\
\hline Pelayanan produk & 3.181 & 0,003 & 0,05 & Signifikan \\
\hline Harga produk & .969 & 0,338 & 0,05 & Tidak Signifikan \\
\hline
\end{tabular}

Sumber : data olahan 2017

Berdasarkan ringkasan hasil uji t seperti yang dikemukakan pada tabel 4.21 diketahui

1. Untuk variabel kualitas produk nilai sig atau probality sebesar 0,000 dalam melakukan penelitian, penulis menggunkan tingkat kesalahan maksimal (level of signifikan ) sebesar $5 \%$ berarti nilai sig t-statistik untuk variabel diferensiasi $0,000<\alpha=0,5$ maka keputusan adalah hipotesis diterima, berarti dapat disimpulkan bahwa variabel kualitas produk $\mathrm{t}$ berpengaruh signifikan terhadap minat beli pada produk sepeda motor honda secara parsial.

2. Untuk variabel desain produk nilai sig atau probality sebesar 0,000 dalam melakukan penelitian, penulis menggunkan tingkat kesalahan maksimal (level of signifikan ) sebesar $5 \%$ berarti nilai sig t-statistik untuk variabel 
diferensiasi $0,0,00<\alpha=0,5$ maka keputusan adalah hipotesis diterima, berarti dapat disimpulkan bahwa variabel desain produk berpengaruh signifikan terhadap minat beli pada produk sepeda motor honda secara parsial

3. Untuk variabel pelayanan produk nilai sig atau probality sebesar 0,003 dalam melakukan penelitian, penulis menggunkan tingkat kesalahan maksimal (level of signifikan ) sebesar $5 \%$ berarti nilai sig t-statistik untuk variabel diferensiasi $0,003<\alpha=0,5$ maka keputusan adalah hipotesis diterima, berarti dapat disimpulkan bahwa variabel pelayanan produk tberpengaruh signifikan terhadap keputusan pembelian pada produk sepeda motor honda secara parsial.

4. Untuk variabel harga produk nilai sig atau probality sebesar 0,338 dalam melakukan penelitian, penulis menggunkan tingkat kesalahan maksimal (level of signifikan ) sebesar 5\% berarti nilai sig t-statistik untuk variabel diferensiasi $0,338>\alpha=0,5$ maka keputusan adalah hipotesis ditolak, berarti dapat disimpulkan bahwa variabel harga produk tidaks berpengaruh signifikan terhadap keputusan pembelian pada produk sepeda motor honda secara parsial

\section{Uji F}

Tabel 4.22

Hasil Uji F

\begin{tabular}{|l|l|l|l|l|}
\hline Variabel & F-hit & Sig & Alpha & Kesimpulan \\
\hline $\begin{array}{l}\text { Kualitas produk, desain } \\
\text { produk,pelayanan produk, } \\
\text { harga produk }\end{array}$ & 618.278 & 0.000 & 0,05 & Signifikan \\
\hline
\end{tabular}

Sumber : data olahan 2017

Berdarsarkan hasil ringkasan hasil uji $\mathrm{F}$ yang di kemukakan pada tabel 4.17 diketahui variabel kualitas produk, desain produk, pelayanan produk dan harga produk di temukan nilai sig atau probality sebesar 0,05 dalam melakukan penelitian, penulis melakukan tingkat kesalah maksimal (level of signifikan) sebesar $5 \%$ berarti nilai F-statistik untuk variabel lainnya $0,000<\alpha$ $=0,5$ maka keputusan adalah Ha diterima dan Ho ditolak. Berarti dapat disimpulkan bahwa variabel kualitas produk, desain produk, pelayanan produk, dan harga produk memiliki pengaruh yang signifikan terhadap minat beli konsumen pada sepeda motor honda secara serempak.

\section{KESIMPULAN}

Berdasarkan hasil penelitian kepada pengguna sepeda motor merk honda di lubuk alung yang berjumlah 50 orang, di kemukakan kesimpulan sebagai berikut Berdasarkan uraian pada bab sebelumnya maka penulis mengambil kesimpulan sebagai berikut :

1. Dari hasil penelitian uji validitas dapat disimpulkan bahwa 3 dari 4 pertanyaan variabel Atribut produk (X1) yaitu kualitas produk valid dan satu pertanyaan no 1 dikatakan tidak valid karna nilai corrected-total 
correlation $<0,003$, desain produk, pelayanan produk dan harga produk, dan minat beli (Y) valid semua karna nilai Corrected-total Correlatian >0,300

2. Dari hasil penelitian berdasarkan uji Reliabel diperoleh nilai Cronbach's Alpha untuk variabel Atribut produk yaitu kualitas produk, desain produk, pelayanan produk dan harga produk, dan minat beli lebih besar dari 0,60. Jadi, item-item pertanyaan untuk variabel penelitian dapat dipakai sebagai alat ukur dalam penelitian.

3. Dari hasil penelitian uji regresi linear berganda dapat disimpulkan dilihat dari nilai a 1475 artinya tampa variabel bebas (variabel X) maka minat beli sepeda motor honda dialer Amanah lubuk alung adalah 1.475 dengan asumsi variabel bebas yaitu kualitas produk,desain produk, pelayanan produk dan harga produk tidak mengalami perubahan. Setiap peningkatan 1 poin variabel kualitas produk, desain produk, pelayanan produk dan harga produk maka peningkatan pada minat beli berubah dengan asumsi maka variabel kualitas produk, desain produk, pelayanan produk dan harga produk di anggap tetap.

4. Dari hasil uji koefisien determinasi diperoleh nilai Adjusted Rsquere sebesar 0.981 yang menunjukan bahwa variabel kualitas produk (X1) , desain produk(X2), pelayanan produk (X3) dan harga produk (X4) mempengaruhi minat beli untuk memilih sepeda motor merk honda $98.1 \%$ sedangkan sisanya $1.9 \%$ dipengaruhi oleh variabel-variabel lain yang tidak diteliti dalam penelitian ini.

5. Dari hasil penelitian berdasarkan uji $\mathrm{T}$ dapat disimpulkan bahwa variabel kualitas produk, desain produk, pelayanan produk, berpengaruh signifikan terhadap minat beli produk sepeda motor merek honda, sedangkan variabel harga produk tidak berpengaruh signifikan terhadap minat beli sepeda motor merek honda.

6. Dari hasil uji $\mathrm{F}$ dapat disimpulkan bahwa variabel kualitas produk, desain produk, pelayanan produk, dan harga produk memiliki pengaruh yang signifikan terhadap minat beli sepeda motor merek honda.

\section{DAFTAR PUSTAKA}

Andika, A., \& Susanti, F. (2018). Pengaruh Marketing Mix Terhadap Keputusan Pembelian Parfum di Azzwars Parfum Lubeg Padang. https://doi.org/10.31227/osf.io/upgc3

Ghozoli, Imam, 2011. Aplika Analisis Mustivarite dengan spss, cetaka Keempat.semarang: Badan penerbit Universitas diponegoro.

Kotler, P. \& Keller, K.L. 1997b. Manajemen Pemasaran. Alih Bahasa oleh Bob Sabran. 2009. Jakarta: Erlangga 
Kotler, Philip dan Gary Amstrong. 2008. Prinsip-Prinsip Pemasaran. Jilid 1 dan 2. edisi Keduabelas. Erlangga. Jakarta.

Kurniawan, R., \& Susanti, F. (2019). Pengaruh Lifestyle Terhadap Keputusan Pembelian Pada Sepatu Merek Fladeo Di Basko Grand Mall Padang. https://doi.org/10.31227/osf.io/ehyauLovelock,Christopher.2002.Service Marketing In Asia.Prentice Hall Inc Singapore.

Lovelock, Christopher H. dan Lauren K. Wright. 2007. Manajemen Pemasaran Jasa. Cetakan II. Indeks. Jakarta

Marlius, D. (2017). Keputusan Pembelian Berdasarkan Faktor Psikologis Dan Bauran Pemasaran Pada PT. Intercom Mobilindo Padang. Jurnal Pundi. Volume 1. No. 1. Hal. 57-66. https://doi.org/10.31575/jp.v1i1.9

Marlius, D. (2016). Pengaruh Bauran Pemasaran Jasa Terhadap Minat Nasabah Dalam Menabung Pada Bank Nagari Cabang Muaralabuh. https://doi.org/10.31227/osf.io/vdqgx

Mayliza, R. (2019). Pengaruh Kesadaran Merek, Asosiasi Merek Dan Perception Of Quality Terhadap Keputusan Pembelian Hospital Bed Merek Paramout Di PT. Aga Medika Utama Padang (Studi Kasus Rumah Sakit Umum Kota Padang). https://doi.org/10.17605/OSF.IO/VYQ4E

Meidisa, C., \& Susanti, F. (2019). Pengaruh Preferensi Dan Pengetahuan Produk Terhadap Minat Menabung Masyarakat Pada Bank Nagari Unit Layanan Syariah Cabang Pasar Raya Padang. https://doi.org/10.31227/osf.io/bf7cr

Nasution.2005. Manajemen Mutu Terpadu. Bogor selatan. Ghalia Indonesia

Aziz, N. (2019). Pengaruh Strategi Promosi Terhadap Keputusan Pembelian Yang Dimediasi Oleh Minat Beli Pada Konsumen Restoran KFC Cabang Khatib Sulaiman Padang. https://doi.org/10.17605/OSF.IO/V92TS

Nugroho, Bhuono Agung. 2005. Strategi Jitu Memilih Metode Statistik Penelitian dengan SPSS. Yogyakarta: Andi.

Parasuraman,A.V.A. Zeithaml, dan L.L. Bery. 1998, A multiple item scale for measuring consumer perceptions of service quality. Journal of retailing, vol. 64, no.1 
Priyanti,Y. Susanti, F. Aziz, N. (2017). Minat Beli Konsumen Toko Sepatu Bata Dipasar Raya Padang Dilihat Dari Sikap Dan Iklan. Jurnal Pundi, Vol. 01, No. 02

Sugiyono. 2003. Metode Penelitian Bisnis. Bandung. Pusat Bahasa Depdiknas

Sukmadinata, N. S. 2011. Metode penelitian pendidikan. Cetakan ke 7. Ba: remaja rosdakarya

Susanti, F. (2015). Pengaruh Bauran Promosi Terhadap Keputusan Klien Dalam Memilih Radio Carano Sebagai Media Promosi Iklan. https://doi.org/10.31227/osf.io/b9ws7

Susanti, F. (2018). Faktor Faktor Yang Mempengaruhi Minat Beli Pada E-Commerce Lazada.co.id (Studi Pada Mahasiswa Jurusan S1 Manajemen "STIE KBP” Padang). https://doi.org/10.31227/osf.io/um4yw

Susanti, F., \& Gunawan, A. C. (2019). Pengaruh Bauran Promosi Dan Harga Terhadap Keputusan Pembelian Produk Kosmetik Maybelline Di Kota Padang. https://doi.org/10.31227/osf.io/npjqh

Tjiptono, Fandy, Gregorius Chandra dan Dadi Adriana. 2008. PemasaranStrategik, Andi, Yogyakarta.

Tjiptono,Fandy.2000 Manajemen Jasa. Yogyakarta. Andi Offset

Widayati, R. (2019). Aktivitas Pemasaran Produk Tabungan Pada PT. Bpr Rangkiang Denai Payakumbuh Barat. https://doi.org/10.17605/OSF.IO/S3UZM 